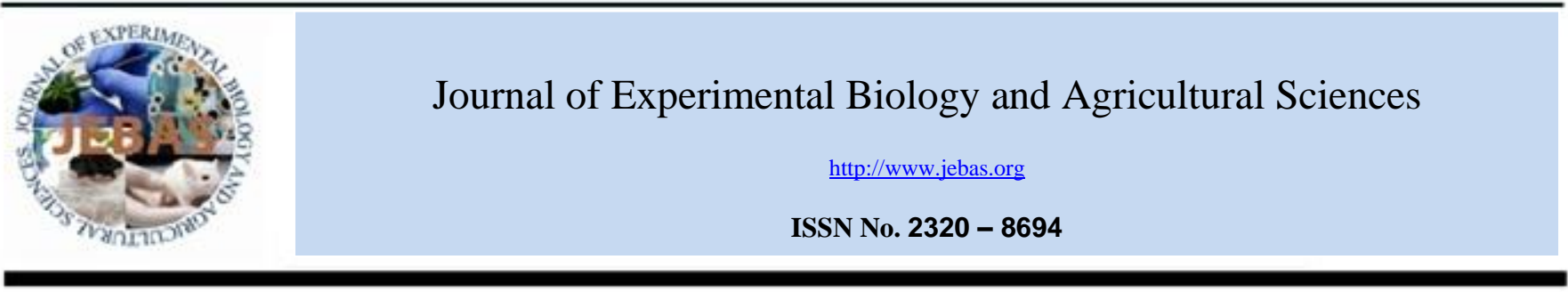

\title{
CLONING AND EXPRESSION PATTERN ANALYSIS OF MmPOD12 GENE IN MULBERRY UNDER ABIOTIC STRESSES
}

\section{Rongfang Li, Dandan Chen, Dominic Kwame Kotoka, Renjie Sun, Yuanliang Deng, Feng Li, Jiao Qian, Rongjun fang, Long Li and Weiguo Zhao*}

School of Biology and Technology, Jiangsu University of Science and Technology, Sibaidu, Zhenjiang, Jiangsu212018,PR China

Received - August 11, 2016; Revision - September 09, 2016; Accepted - December 16, 2016

Available Online - December 29, 2016

DOI: http://dx.doi.org/10.18006/2016.4(VIS).698.705

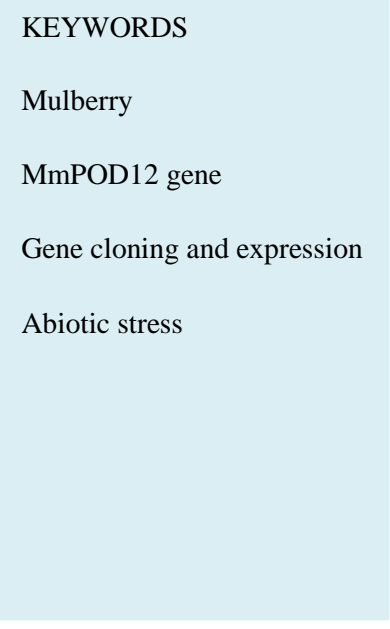

\begin{abstract}
A full-length cDNA denominated as MmPOD12 for peroxidase in mulberry(Morus alba), an enzyme involved in the respiration, photosynthesis, and the oxidation of auxin, was cloned from 'Yu71-1' a variety of mulberry using a rapid amplification of terminal (RACE) approach. The full cDNA of MmPOD12 has1482 base pairs (bp) in length with an open reading frame (ORF) 1050 bp encoding a protein of 349 amino acids residues with a predicted molecular weight of $53.92 \mathrm{kDa}$ and an isoelectric point of 9.35. Sequence analysis revealed that MmPOD12 shares homology with the Morus notabili (M. notabilis C.K.Schn) and has closely related to green plum, strawberry and pear. The expression patterns of MmPOD12 treated with drought, salt and hormones stresses were examined using real-time quantitative PCR (RT-qPCR). These experiments caused significant up-regulation of the expression of MmPOD12 under drought and salt stress. The highest expression level of MmPOD12 appeared at $2 \mathrm{~d}$ for salt stress, and 7d for drought stress, while a significant fluctuation of MmPOD12 expression was detected after ABA and SA stresses. These findings provide a basis for future functional analyses of $M m P O D 12$ gene in Mulberry.
\end{abstract}

* Corresponding author

E-mail: wgzsri@ 126.com (Weiguo Zhao)

Peer review under responsibility of Journal of Experimental Biology and Agricultural Sciences.

Production and Hosting by Horizon Publisher India [HPI] (http://www.horizonpublisherindia.in/).

All rights reserved.
All the article published by Journal of Experimental Biology and Agricultural Sciences is licensed under a Creative Commons Attribution-NonCommercial 4.0 International License Based on a work at www.jebas.org.

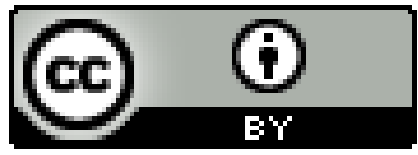




\section{Introduction}

Peroxidase (POD) widely exists in biological world and it plays an extremely important physiological role in plants as it presents from the first hours of a plant's life until its last moments. POD is not the single-minded enzyme of hydrogen carrier except for $\mathrm{H}_{2} \mathrm{O}_{2}$ but it can also catalyze the oxidation reaction of Phenolic, Cytochrome $\mathrm{C}$, Vitamin $\mathrm{C}$, Nitrite, Colorless dye, Indole, Amine and Inorganic ions(especially Iodide ion) with $\mathrm{H}_{2} \mathrm{O}_{2}$. Besides, due to POD can catalyze the decomposition reaction of IAA, a kind of hormone that can promote plant cell elongation, it also played a role in plant tissue differentiation, seed germination and fruit maturity (Passardi et al., 2005).

In addition, POD is very sensitive to the variety of adverse environmental conditions. POD isoenzyme will be produced quickly when plants are infected by bacteria, and rapid induction of POD isoenzyme was related to the denovo synthesis according to the experiments about protein synthesis inhibitors (Hiraga et al., 2001). The level of POD activity was higher when plants were treated with low concentration of ethylene or attacked by pathogens (Tognolli et al., 2002). There are many studies which demonstrated that POD can eliminate the effect of injury caused by $\mathrm{H}_{2} \mathrm{O}_{2}$ during the processes of metabolic in plants (Wu \& Yu,1994; Liang et al.,2003). Further, some studies suggested that POD activity of litchi fruit stored at room temperature was higher than the wet storage. POD have multi functional gene in Ginkgo biloba as it has the potential function on defense aspects, such as it participates in the removing of heavy metal pollution and dealing with the damage (Cheng et al.,2010).

Under some abiotic stress, the activity and expression level of POD were affected. There are some reports which asserted role of POD in overcoming salt stress in plants and the level of POD increased with inducing some stress (Zhu, 2002; Narayanan et al., 2005; Dai et al., 2015). Further, Dai et al. (2015) observed higher POD activities in leaves of Asparagus bean seedling immediately after inducing salt stress by $\mathrm{NaCl}$ $(150 \mathrm{mmol} / \mathrm{L})$. There's a study which found POD activity in leaves of Populus Euphratica and it increase with the aggravation of drought stress (Wang et al., 2013). Other papers also reported that drought stress induced the level of POD activity in Crassulaceae plant (Wen et al., 2014) and Lagerstroemia indica seedling (Liu et al., 2015). Studies on role of gene expression on POD activity suggested that under stresses of Abscisic acid (ABA) and Salicylic acid (SA), the level of POD activity change (Fang et al., 2014; Fang et al., 2014; Xu et al., 2015). Study on the effect of exogenous ABA induced stress on the seed germination and cold tolerance of winter rape seedlings, showed that the level of POD activity significant increased and the cold resistance is optimum when ABA concentration is $30 \mathrm{mg} / \mathrm{L}$ (Fang et al., 2014).

In this study, cloning of the POD12 gene in Mulberry based system on the expressed sequence tags (ESTs) from mulberry
cDNA library was constructed by following the method of Zhao (2008) and Fang et al. (2008), and we named it MmPOD12.The purpose of this study is to got the full-length sequence and analyzed the expression of the gene under different kinds of stresses in mulberry. These results provide a new breeding strategy for improving mulberry resistance.

\section{Materials and Methods}

\subsection{Plant materials}

Mulberry (Morus alba) variety 'Yu71-1', obtained from the Sericultural Research Institute, Chinese Academy of Agricultural Sciences, Zhenjiang, China, was used as the experimental material. To analysis MmPOD12 gene expression pattern under various stresses, 'Yu71-1' grafting seedlings were grown under standard conditions that the temperature is maintained at $25^{\circ} \mathrm{C}$ and the photoperiod is $12 \mathrm{~h}$ in an incubator, until the winter shoots reached approx. $30 \mathrm{~cm}$ in length $(50 \mathrm{~d})$.

\subsection{RNA isolation and synthesis of the first strand cDNA}

Total RNA was isolated from fresh buds (approx. $90 \mathrm{mg}$ ) of the grafted Mulberry seedlings using the RNAprep Plant kits (TaKaRa Biotechnology Co. Ltd., Dalian, P. R. China) and following the manufacturer's protocol, and then stored at $-80^{\circ} \mathrm{C}$ re-suspended in $0.1 \%(\mathrm{v} / \mathrm{v})$ diethylpyrocarbonate (DEPC)treated water. RNA quality was determined with UV spectrophotometer and by $1.0 \% \quad(\mathrm{w} / \mathrm{v})$ agarose gel electrophoresis.

The first strand cDNA was synthesized from $9 \mu$ total RNA (1.0 $\mathrm{ng} \mathrm{ml}^{-1}$ ) from the previous step using the RNase $\mathrm{H}-$ Reverse Transcriptase M-MLV kit (TaKaRa Biotechnology Co. Ltd.). Following the manufacturer's instructions, the reaction conditions are $42^{\circ} \mathrm{C}$ for $60 \mathrm{~min}$ with $4.0 \mu 1$ oligo-dT $\left(100 \mu \mathrm{g} \mathrm{ml}^{-1}\right)$ and adaptor primer in a total volume of $20 \mu \mathrm{l}$.

\subsection{Molecular cloning of the full-length MmPOD12 cDNA}

The first strand cDNA was used as the template for PCR in gene cloning. The forward and reverse primers were designed according to the EST with the inference function from the mulberry cDNA library (MmPOD12 Forward primer: 5'TAGATGCCACCGACACGGT-3'; MmPOD12 Reverse primer: 5'-ACTTGGATTCCTAGCAGAGC-3'). The RT-PCR reactions system were performed in a total volume of $50 \mu \mathrm{L}$

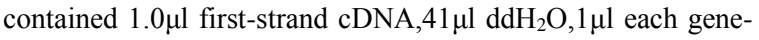
specific primer, $0.5 \mu \mathrm{l} \mathrm{dNTPs}(10 \mathrm{mM}), 5 \mu \mathrm{l}$ buffer, and $0.5 \mu \mathrm{lTaq}$ DNA polymerase $(5 \mathrm{U} / \mathrm{mL})$ (TaKaRa Biotechnology Co. Ltd.). The PCR amplification condition: initial denaturation at $94^{\circ} \mathrm{C}$ for 5 min firstly; then there are 32 cycles of denaturation at 94 ${ }^{\circ} \mathrm{C}$ for $35 \mathrm{~s}$, annealing at $60^{\circ} \mathrm{C}$ for $45 \mathrm{~s}$, and elongation at $72^{\circ} \mathrm{C}$ for $1 \mathrm{~min}$; finally, extension at $72{ }^{\circ} \mathrm{C}$ for $10 \mathrm{~min}$.

The RT-PCR products were detected by gel electrophoresis (1\% agarose gels) and purified following the Takara Agarose 
Gel DNA Purification Kit (TaKaRa Biotechnology Co. Ltd.) following the manufacturer's protocol. The purified fragment was then cloned into the pMD18-T vector and sequenced. It was reported that cDNA sequence is the MmPOD12 gene, but 3'-UTR and 5'-UTR is incomplete. In order to get the full length, we used 3' and 5' rapid amplification of cDNA ends (RACE) technology using the Clontech SMART ${ }^{\mathrm{TM}}$ RACE Kit (TaKaRa Biotechnology Co. Ltd.).

In 3 ' end reverse transcription reaction, the cDNA which was synthesized from $9 \mu \mathrm{L}$ total RNA by Reverse Transcriptase M$\operatorname{MLV}\left(\mathrm{RNaseH}^{-}\right)$at $42^{\circ} \mathrm{C}$ for $1 \mathrm{~h}$ with $4 \mu \mathrm{L} 3$ 'ap primer (in a total volume of $20 \mu 1$ ), was used as a template. The genespecific primer is GSP1:5'ACAACAGCAGCATCGCCAACC-3'). 3'RACE-PCR amplifications condition: denaturation at $94{ }^{\circ} \mathrm{C}$ for $5 \mathrm{~min}$; followed by 35 cycles of denaturation at $94{ }^{\circ} \mathrm{C}$ for $40 \mathrm{~s}$, annealing at $62^{\circ} \mathrm{C}$ for $45 \mathrm{~s}$, and elongation at $72{ }^{\circ} \mathrm{C}$ for $60 \mathrm{~s}$; with a final extension at $72^{\circ} \mathrm{C}$ (Tong et al., 2013).

The $5^{\prime}$ end reverse transcription reaction following the instructions of SMART $^{\mathrm{TM}}$ RACE cDNA Amplification Kit (CLONTECH Co. Ltd.). The 5'-RACE reaction system as followed: $1 \mu \mathrm{l}$ cDNA template, $17.25 \mu \mathrm{l}$ ddH2O,1 $1 \mu \mathrm{l} 5^{\prime}$ end specific primer (GSP2 : 5'ATGACAGGGTCTTGGGTGGGATAGAG-3'), $1 \mu$ l common primer, $2 \mu \mathrm{l}$ dNTP, $2.5 \mu \mathrm{l}$ buffer, and $0.25 \mu \mathrm{l}$ rTaq DNA polymerase $(5 \mathrm{U} / \mathrm{mL})$, in total $25 \mu \mathrm{L}$; and the reaction condition is that: initial denaturation at $94^{\circ} \mathrm{C}$ for $5 \mathrm{~min}$; then 5 cycles of denaturation at $94^{\circ} \mathrm{C}$ for $30 \mathrm{~s}$, annealing at $72^{\circ} \mathrm{C}$ for $30 \mathrm{~s}$, elongation at $72^{\circ} \mathrm{C}$ for $2 \mathrm{~min}$; then 5 cycles of denaturation at $94^{\circ} \mathrm{C}$ for $30 \mathrm{~s}$, annealing at $68^{\circ} \mathrm{C}$ for $30 \mathrm{~s}$, elongation at $72^{\circ} \mathrm{C}$ for $2 \mathrm{~min}$; and then followed by 25 cycles of denaturation at 94 ${ }^{\circ} \mathrm{C}$ for $30 \mathrm{~s}$, annealing at $66^{\circ} \mathrm{C}$ for 30 s, elongation at $72{ }^{\circ} \mathrm{C}$ for 2 min; and the final extension at $72^{\circ} \mathrm{C}$ for $7 \mathrm{~min}$. The $3^{\prime}$ and $5^{\prime}$ ends RACE products were all analyzed by Gel electrophoresis.

\subsection{Bioinformatics analysis of the MmPOD12gene}

The cloned gene sequence was analyzed for identity and homology using the National Center for Biotechnology Information (NCBI) online Search Tool (BLAST) (http://www.ncbi.nlm.gov/). And the ORF of MmPOD12 was using the ORF finder program at NCBI (http://www.ncbi.nlm.nih.gov/gorf/orfig.cgi) and downloading the homology nucleotide sequences from the database. Then use the DNA Star software to splice various DNA fragments and analyses it.

The MmPOD12 protein structure and functional domains were predicted using the tools of ExPASy (http://prosite.expasy.org/prosite.html/) and PSORT the software on line. The molecular mass and the theoretical isoelectric point were predicated using the software DNAStar and ExPASy-ProtParam (http://web.expasy.org/protparam/). Subsequently, using the ClustalX program and DNAMAN software to align and compare the multiple amino acid sequences of POD genes from different species. The on line software SWISS-MODEL (http://swissmodel.expasy.org/) was used to the prediction of $M m P O D 12$ protein tertiary structure. Finally, software MEGA5.1 and clustalx were used to generate the phylogenetic tree of the POD proteins from different species by the neighbor-joining (NJ) method. The bootstrap analysis based on One thousand replicates, and the Protein domains were predicted using SMART (http://smart.emblheidelberg.de/) package.

2.5 MmPOD12expression patterns under stresses using qRTPCR

Mulberry (M. alba) 'Yu71-1' grafting seedlings were planted in the same specification pots, and each pot containing only one seedling. The growing conditions were controlled with a $16 \mathrm{~h}$ photoperiod and $25^{\circ} \mathrm{C} / 22^{\circ} \mathrm{C}$ (day/night, respectively). After approximately 2 months, when the shoots had reached approx. $20 \mathrm{~cm}$ in length, the seedlings were subjected to salt (0.3mol/LNaCl,irrigate), drought (PEG-6000,20\%), ABA $(0.1 \mathrm{~mol} / \mathrm{L}$, spray $)$ and $\mathrm{SA}(0.1 \mathrm{~mol} / \mathrm{L}$, spray) respectively.

The leaf samples (approx. 1.0g) were collected in $6 \mathrm{~h}, 12 \mathrm{~h}, 1 \mathrm{~d}, 2 \mathrm{~d}, 3 \mathrm{~d}, 4 \mathrm{~d}, 16 \mathrm{~d}$ after the initiation of salt treatment; in $2 \mathrm{~d}, 4 \mathrm{~d}, 8 \mathrm{~d}, 10 \mathrm{~d}, 16 \mathrm{~d}$ after the initiation of drought treatment; and in $2 \mathrm{~h}, 4 \mathrm{~h}, 6 \mathrm{~h}, 8 \mathrm{~h}, 10 \mathrm{~h}, 1 \mathrm{~d}, 2 \mathrm{~d}, 3 \mathrm{~d}$ after the initiation of ABA and SA treatment respectively.

To reveal the putative biological function of the MmPOD12 protein, qRT-PCR method was used to analysis the expression levels of MmPOD12 gene under the four abiotic stresses. The first-strand cDNA was reversely transcribed from total RNA as the directions of the Prime script RT Reagent Kit (TaKaRa Biotechnology Co. Ltd, Dalian, P. R. China), and PCR was carried out following the SYBR Premix Ex Taq Kit(TaKaRa Biotechnology Co. Ltd.) directions. The reaction system was performed in total $20 \mu \mathrm{l}$ volume, containing $10 \mu \mathrm{l} \mathrm{SYBR}^{\circledR}$ Premix Ex TaqTM,0.5 $\mu$ l Rox Reference Dye (50×), $0.5 \mu$ each primer solution, $1.5 \mu \mathrm{l}$ reverse transcription product, and then add RNase-free water. The mulberry Maactin gene ( $\beta$-actin) (GeneBank access No. DQ785808) was used for internal control to allow for normalization by visual inspection of mRNA level. The Forward primer ( $\beta$-actin-F:5'GACAATGGAACTGGAATGG-3') and the Reverse primer ( $\beta$-actin-R:5'-GACCCTCCAATCCAGACA-3') were used for PCR amplification. The reaction conditions as follows: first, initial denaturation at $95^{\circ} \mathrm{C}$ for $10 \mathrm{~min}$; then, followed by 45 cycles of denaturation at $95^{\circ} \mathrm{C}$ for $15 \mathrm{~s}$, annealing at $58^{\circ} \mathrm{C}$ for $20 \mathrm{~s}$, extension at $72^{\circ} \mathrm{C}$ for $20 \mathrm{~s}$; and then at $95^{\circ} \mathrm{C}$ for $15 \mathrm{~s}$, at $60^{\circ} \mathrm{C}$ for $1 \mathrm{~min}$; finally, end at $95^{\circ} \mathrm{C}$ for 15 minutes.

The result of PCR was analyzed by the Applied Biosystems 7300 System SDS Software and analyzing RT-PCR data by the comparative CT method (Livak \& Schmittgen, 2001). Then calculating the average values for MmPOD12 gene expression in the two biological replicates, and the standard errors. 


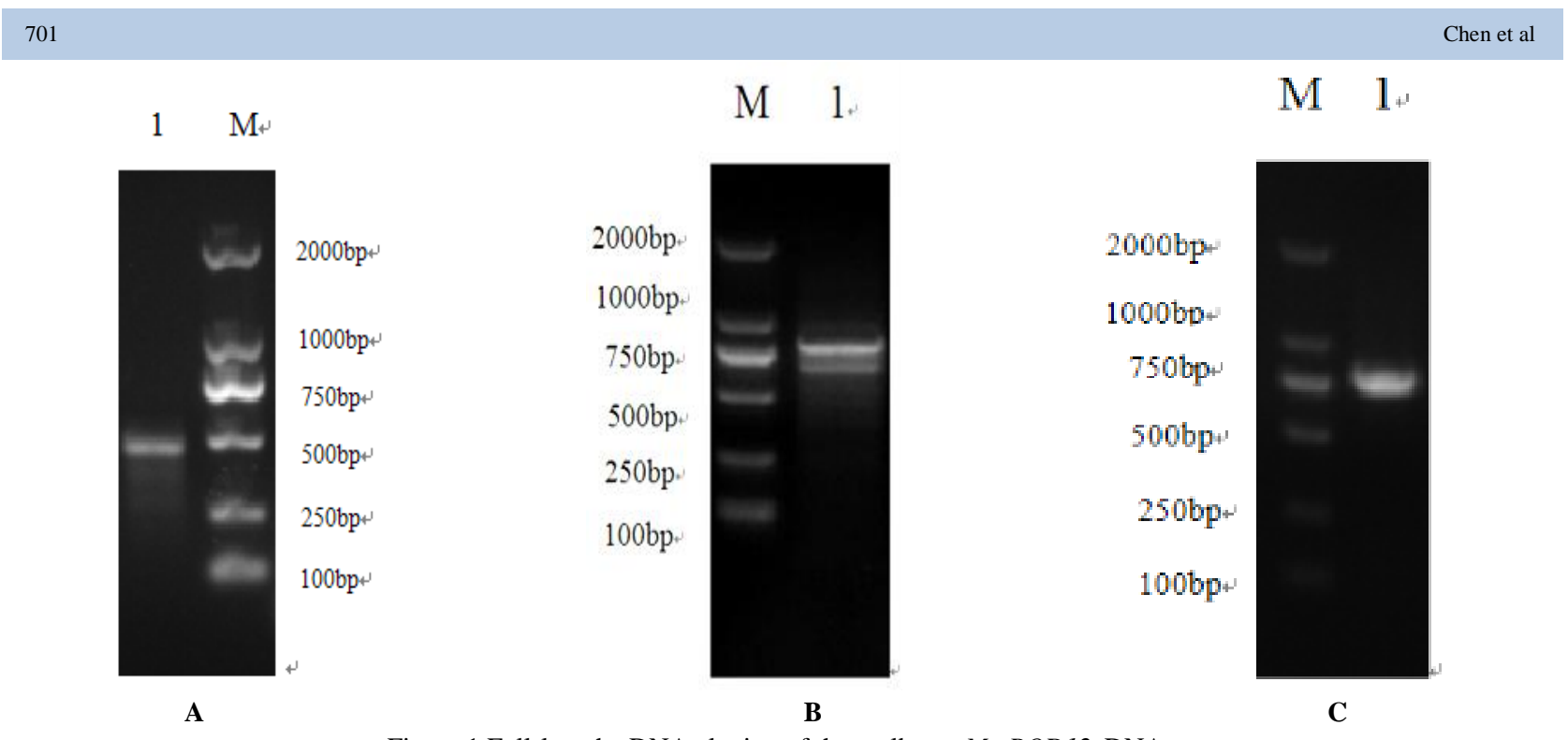

Figure 1 Full-length cDNA cloning of the mulberry MmPOD12cDNA.

(A) RT-PCR amplification of a cDNA fragment from the mulberry MmPOD12 gene. Lane 1, Product of RT-PCR.

(B) 3'-RACE amplification products of a cDNA from the mulberry MmPOD12gene.Lane 1,Product of 3'-RACE.

(C) 5'-RACE amplification products of a cDNA from the mulberry MmPOD12 gene.Lane 1, Product of 5'-RACE. Lanes M, DL2000

DNA markers (TaKaRa Biotechnology Co. Ltd.).

\section{Results}

\subsection{Gene cloning and bioinformatics analysis of MmPOD12}

The mulberry cDNA library screening technique and the clone technology combining bioinformatics analytical methods were used to obtain a cDNA of the Mulberry POD gene and the RTPCR products were analyzed by gel electrophoresis (1\% agarose) (Gao et al., 2010) and get a expected size (approximately $500 \mathrm{bp}$ ) band was determined according to the EST sequence (Figure. 1A) (Fang et al., 2008). 3' and 5' RACE technology was used to obtain a full-length cDNA of Mulberry $P O D$ gene, which contained a 780 bp fragment (3'-RACE product, Figure. 1B) and a $750 \mathrm{bp}$ fragment (3'-RACE product, Figure. $1 \mathrm{C}$ ), then the full-length cDNA of the mulberry $P O D$ gene was obtained. This is the first time cloned $P O D$ gene of mulberry, and it was designated the gene as MmPOD12 (Patent number:101510163922.9). Sequence analysis showed that the isolated cDNA from 'Yu71-1' is a small gene with a $1482 \mathrm{bp}$ full-length, which contains a 1050 bp ORF encoding a proteinof349 amino acids, and it was predicted that the molecular weight of the protein is $53.92 \mathrm{kDa}$ and the isoelectric point is 9.35 (Figure. 2).

\begin{abstract}
According to software Batch CD-search (http://www.ncbi.nlm.nih.gov/Structure/cdd/wrpsb.cgi), we find that there is a conserved domain contained by MmPOD12 gene structure. This conserved domain can be regard as position-specific score matrices (PSSMs) when identifying the conserved domains in protein sequences by RPS-BLAST.
\end{abstract}

3.2 Sequence analysis of MmPOD12
The homologous alignment and deduced amino acid sequences of MmPOD12were analyzed using the software Clustal X2.0 program (http://www.clustal.org/) and Vector NTI Advance 11.The results showed that the length and structure of MmPOD12 homologous sequences are relatively similar with other seven species. Homology analysis revealed that MmPOD12 is highly conserved among mulberry different species, but there are three different amino acids in 'Yu71-1' and Morus notabilis, this mean there are particularities in different species.

According to the MmPOD 12 amino acid sequence structuring the evolutionary tree by MEGA5.1 Software. The results was visualized in Figure. 3 that the length and structure of the 16 species amino acid sequences are very conservative. There is relatively close homology between 'Yu71-1' and Morus notabilis, but the homology is far between 'Yu71-1'and Eucalyptus grandis, Grape, Populus euphratica, Populus trichocarpa and Litchi.

\subsection{Stress-induced MmPOD12 gene expression}

To further analysis whether the level of MmPOD12 gene expression is induced by various abiotic stresses, it was monitored that the MmPOD12 mRNA levels under abiotic stresses by qRT-PCR (Figure.4) illustrates that, the expression level of MmPOD12 gene fluctuates obviously under salt stress, the overall trend is decreasing at the initial of salt treatment, followed there is a sharpest rise and up to a maximum, and then decrease slowly (Figure.4A). 
1

AGCGAAAGCTTTGTATATAATAAATGATTTACCCACCATAGTGCATAAAAAGTGCTGCTGATGAAGTCTCTTGGTCTAATAT CACTGCTCTTGCAGCGCATGATTCTGTTTTCCTGCTTCGTGGTGGTGACTATGCATCACGATCACCTGAA 152

153 atg gctacagataacgttgttgttgtgatgacgatgatgatgatgatctgtgtaagttgtgtcgtttatgcacataaatcatcagatgtg

M A T D N V V V V M T M M M M I C V S C V V Y A H K S S D V

243 cctcttgctgaaggactgtcttggagcttctatgacaagagctgtccagatgctgagtccatcataagaactcaactcaagaaggttttc

P L A E G L S W S F Y D K S C P D A E S I I R T Q L K K V F

333 aacgaggacattggccaagctgctggcttgcttcgtctccatttccatgactgctttgttcagggttgtgacgggtcagtgttgttggac

N E D I G Q A A G L L R L H FH D C F V Q G C D G S V L L D

423 gggtcggcgagtgggccggacgagaagaacgcgcetccgaacctgagtttaagagcgaaggcttttgagataataaacgatctacgcgcc

G S A S G P D E K N A P P N L S L R A K A F E I I N D L R A

513 agagttcataagaagtgcggtcgagtcgtctcttgttctgatatcgctgctattgcagcacgtgattctgttttcttgtcaggtggccct

R V H K K C G R V V S C S D I A A I A A R D S V F L S G G P

603 gactatgcagtaccattaggaagaagagacgggttgacatttgcgacaagagcagtaactatagccaaccttccttcatcaacaagcaac

D Y A V P L G R R D G L T F A T R A V T I A N L P S S T S N

693 gctagcactatcgtcgcctttcttgcaacgaaaaactagatgc actgacgcggttgccetttcaggcggccacaccattggcettagc

A S T I V A F L A T K N L D A T D A V A L S G G H T I G L S

783 aattgctcctccttaacaaccgcctctatcccacccaagaccetgtcatggaccagacttttgccaaaaacctaaaggegatttgcccc

N C S S F N N R L Y P T Q D P V M D Q T F A K N L K A I C P

873 acgaacatcacggttgccactactgtgctcgatattcgaagccctaatgccttgacaacaagtactatgtcaaccttatgaaccgccaa

T N I T V A T T V L D I R S P N A F D N K Y Y V N L M N R Q

963 ggactcttcacatctgatcaggatttgtacagctacagtaagaccaaggacattgtcatcaacttcgccgttaatcaatcactcttcttc

G L F T S D Q D L Y S Y S K T K D I V I N F A V N Q S L F F

1053gaaaaattcatcatcgccatgactaaaatgggccaattaagtgtcttgacaggcagccaaggtgagatacgtgccaattgctctgctagg

E K F I I A M T K M G Q L S V L T G S Q G E I R A N C S A R

1143aatccaagtaaggataacttggcgtctctatatgagtatgtggacaacttgtcggcgttctaa

N P S K D N L A S L Y E Y V D N L S A F *

GGGCTTTAGGTTTTGGCTTTGTTTCAAAGATGTTCCTTTTGTTAAAAAAAAAAAAAAAAAAAAAAAAAAAAAAAAAAAACC TTGTGGGGCCTCTC

CGTGGGGTAATGCAGACCATCCTTTTGGGGGGTTCGGCTTTGTCACCCTTGTTCCCAAGTTTGTTGATTAATTGTTTATGGGT

TGAATGGTAAGG

TCTTTGACCATCCATCGCGAGACAAAAAAACTTGGGGGTGTTGGTCTTCTTTTTAGTAAATATAAGGGGGCAATCTAGTGTT

TAAGT 1482

Figure 2 The nucleotide and deduced amino acids sequence of mulberry MmPOD12

ATG indicates the start codon ; TAA indicates the stop codon

After the drought stress, the expression level of MmPOD12gene change little at the initial days, it begin to increase in $8 \mathrm{~d}$ and continued to grow (Figure. 4B). The expression level of MmPOD12underABA and SA stresses showed a significant wave as it increase firstly and then decrease (Figure.4C and Figure.4D). According to the qPCR analysis, we initially speculated that MmPOD12 is related to mulberry resistance, especially in salt and drought stresses.

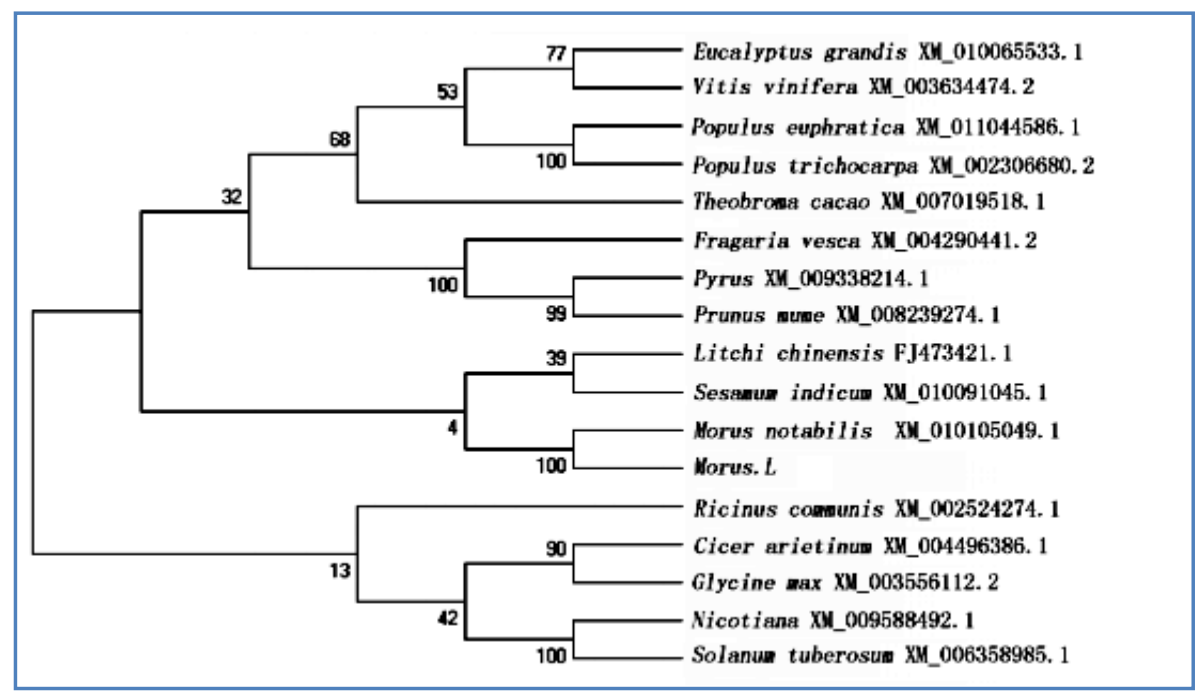

Figure 3 The phylogenetic tree based on amino acid sequence of MmPOD12 and other homologues sequences. 

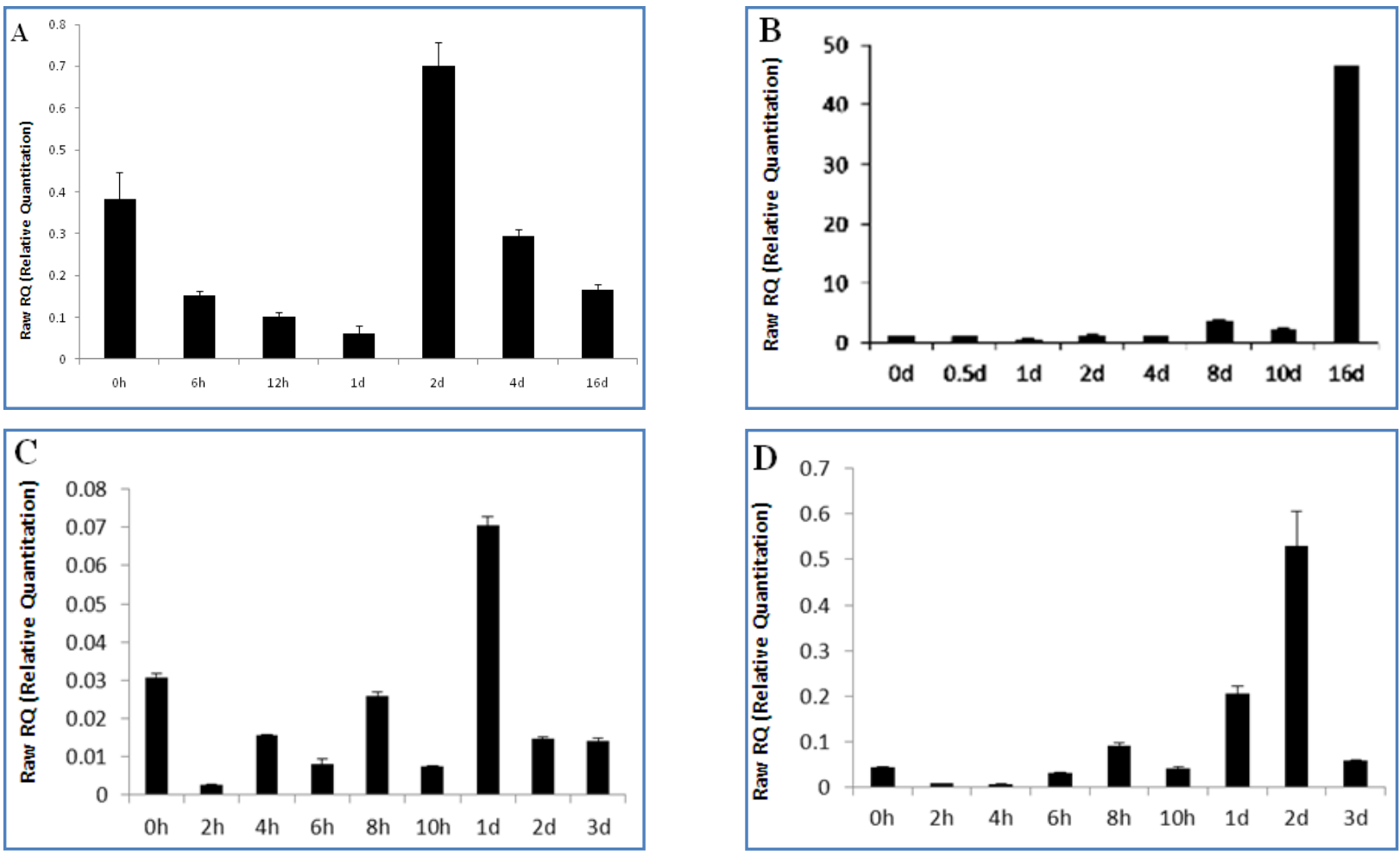

Figure 4 Analysis of $M m P O D 12$ expressing under drought, salt, ABA and SA stresses.

(A): Analysis of $M m P O D 12$ expressing in $0 \mathrm{~h}, 6 \mathrm{~h}, 12 \mathrm{~h}, 1 \mathrm{~d}, 2 \mathrm{~d}, 4 \mathrm{~d}$ and $16 \mathrm{~d}$ under salt stress. (B) Analysis of MmPOD12 expressing in $0 \mathrm{~d}$, 0.5d, 2d, C: 4d, 8d, 10d and16dunder drought stress. (C)Analysis of MmPOD12 expressing in 0d, 2h,4h,6h,8h,10h,1d, 2d and 3d under

ABA stress. (D) Analysis of MmPOD12 expressing in 0d, 2h,4h,6h,8h,10h,1d, $2 \mathrm{~d}$ and $3 \mathrm{~d}$ under SA stress.

\section{Discussions}

In this study, a full-length cDNA sequence of $P O D$ from mulberry variety 'Yu71-1'was obtained for the first time by cloning technology. It was analyzed the gene's sequence, expression pattern and predicted the protein coded by it and explored the expression level of MmPOD12 under various abiotic stresses. In this study, it was reported that MmPOD12 can compared with the $P O D$ in other species with a higher homology, an identical conserved regions and a similar tertiary structure. When mulberry plants were in adverse environments such as salt and drought, the expression level of MmPOD12 will adjust to response to environmental stresses.

The adjustment mechanism of MmPOD12 was understood preliminarily. The results of qRT-PCR analysis shows that the expression level of MmPOD12 mRNA significantly increased under salt stress, and the expression level up to the highest in 6 $\mathrm{h}$ after treatment. This indicates that the adversity like salt affect MmPOD12 gene expression and over expression. This present result was consistent with the previous reports that the POD genes played an important role during the plants' physiological mechanisms adapting to salinity change (Du et al., 2011).
Under drought stress, the transcriptional level of MmPOD12 mRNA will increase gradually with the extension of time and there is a sharp increase peak at the later period. This indicates that, under mild and moderate drought treatment,MmPOD12 activity was modest overall increase as the plants against the damage caused by drought stress through other path mainly; and when mulberry plants under severe drought environment, MmPOD12 activity increased significantly as it participating in resisting the drought stress. This is consistent with other species with strong drought resistance (Peng et al., 2005).

Under $\mathrm{ABA}$ and $\mathrm{SA}$ stresses, the expression levels of $M m P O D 12$ increased, and the effect of SA more obvious than ABA. This suggests that spraying exogenous ABA can improve $P O D$ activity and this is consistent with the study result of Fang et al. (2014).

To summarize, a full length cDNA of MmPOD12 was isolated from mulberry variety 'Yu71-1' and characterized in this paper. Multiple alignments and bioinformatics analysis results showed that the deduced MmPOD12 had high similarity to other plant PODs. Expression profiles of MmPOD12 under different treatments suggest that MmPOD12 was a stressresponsive gene, especially to salt and drought. The cloning, 
characterization and expression analysis of MmPOD12 will be helpful to understand more about its role in the resistance to stresses for plant, which provide the basis for improving the ability to anti-stress by genetic manipulation in the near future.

\section{Acknowledgments}

This work was supported by the Public Industry (Agriculture) Specific Research Programme (201403049), the Sericulture Industry Technology in China Programme (CARS-22-ZJ0308), the Crop Germ plasm Resources Protection Project (2014NWB024), the Research and Innovation Project for College Graduates of Jiangsu Province (1252161418). China Postdoctoral Science Foundation funded project (2014M551605), Jiangsu Planned Projects for Postdoctoral Research Funds (1401084B) and Natural Science Foundation of China (31400448).

\section{Conflict of interest}

Authors would hereby like to declare that there is no conflict of interests that could possibly arise.

\section{References}

Cheng H, Li LL, Wang Y, Cheng SY (2010) Molecular Cloning, Characterization and Expression of POD1 gene from Ginkgo biloba. Acta Agriculturae Boreali-Sinica 25: 44-51.

Dai QL, Wang JL, Ma ML, Lv XC, Guo C, Wang J, Du SZ. (2015) Effects of $\mathrm{NaCl}$ stress on antioxidant enzyme activities in Asparagus Bean Seedlings. Jiangsu Agricultural Sciences 43: 193-196.

Du SZ, Dai Q, Feng B, Xie L, Yang J, Wang J (2011) Changes of Antioxidant Enzymes Activities in Cowpea (Vigna unguiculata Linn.) Seedlings under Different Concentrative $\mathrm{NaCl}$ Stress. Genomics and Applied Biology 30: 351-356. DOI: $10.3969 /$ gab.030.000351.

Fang RJ, Qi JL, Hu DQ, Zhao WG, Wang W, Zhang L, Liu L, Pan G, Shen XJ, Pan YL, Yang YH (2008) Construction of cDNA expression library from the young leaves of mulberry and EST Analysis. Sericulture Science 34: 581-586.

Fang Y, Wu JY, Sun WC, Yang JX, Han HM, Han YW, Chen YP (2014) Inducing effects of exogenous ABA on seed germination and cold tolerance of winter rape seedlings. Agricultural Research in the Arid Area 32: 70-74. DOI : 10.7606/j.issn.1000-7601.2014.06.012.

Gao Y, Zhao Y, Li T, Ren C, Liu Y, Wang M (2010) Cloning and characterization of a $\mathrm{G}$ protein $\beta$ subunit gene responsive to plant hormones and abiotic stresses in Brassica napus. Plant Molecular Biology Reporter.28: 450-459. DOI:10.1007/s11105-009-0169-1.
Hiraga S, Sasaki K, Ito H, Ohashi Y, Matsui H (2001) Alarge family of class III plant peroxidases. Plant \& Cell Physiology 42:462-468. doi: 10.1093/pcp/pce061.

Liang Y, Hu X, Zhang Z, Liu X (2003) Progress on Physiological Function Research of Plant Peroxidase. Journal of Inner Mongolia Agricultural University (Natural Science Edition) 2: 110-113.

Liu X, Wang Z, Tan J (2015) Effect of water stress on growth and physiological and biochemical characteristics of Lagerstroemia indica. Jiangsu Agricultural Sciences 10: 239241.

Livak KJ, Schmittgen TD (2001) Analysis of relative gene expression data using real-time quantitative PCR and the $2^{-\Delta \Delta C t}$ method. Methods 25:402-8. doi:10.1006/meth.2001.1262.

Narayanan S, Ruma D, Gitika B, Sharma SK, Pauline T, Ram MS, Ilavazhagan G, Sawhney RC, Kumar D, Banerjee PK (2005) Antioxidant activities of seabuckthorn (Hippophae rhamnoides) during hypoxia induced oxidative stress in glial cells. Molecular and Cellular Biochemistry 278 : 9-14. doi:10.1007/s11010-005-7636-2.

Passardi F, Cosio C, Penel C, Dunand C (2005) Peroxidases have more functions than a Swiss army knife. Plant Cell Reports 24:255-265. DOI: 10.1007/s00299-005-0972-6.

Peng Q, Ye-ju L, Fei-hu L (2005) Effects of drought stress on SOD and POD activities in tobacco leaves. Chinese Tobacco Science $2: 28-30$.

Tognolli M, Penel C, Creppin J, Simon P (2002) Analysis and expression of the large class III peroxidase gene family in Arabidopsis thaliana. Gene 288: 129-138. http://dx.doi.org/10.1016/S0378-1119(02)00465-1

Tong W, Zhang Y, Wang H, Li F, Liu Z, Wang Y, Fang R, Zhao W, Li L (2013) Mulberry (Morus alba L.) methionine sulfoxide reductase gene cloning, sequence analysis, and expression in plant development and stress response. Russian Journal of Bioorganic Chemistry 39: 522-529. DOI: $10.1134 / \mathrm{S} 1068162013050154$

Wang Y, Jiao P, Gu Y, Zhang S, Li Z (2013) Study on the relationship between leaf shape changes and POD isozyme in Populus euphratica. Journal of Arid Land Resources and Environment 4 : 181-186.

Wen YL, Zhang WJ, Shao CF, Zhu GY, Guo JL (2014) Effects of high temperature and drought stress on lipid peroxidation and protective enzyme activities in two Sedum plants. Journal of Inner Mongolia Agricultural University (Natural Science Edition) 35: 37-40. 
Wu MJ, Yu P (1994) The physiological functions of plant peroxidase. Journal of Biology 6: 14-16.

Xu S, Shi XY, Li Q (2015) Effects of Exogenous ABA on Chilling Resistance of Pepper Seedlings. Journal of Changjiang Vegetables 24: 55-58.
Zhao WG (2008) Construction of mulberry cDNA library and analysis of genetic diversity. Post doctoral thesis submitted to Nanjing University.

Zhu JK (2002) Salt and drought stress signal transduction plants. Annual Review of Plant Biology 53:247-273. DOI: 10.1146/annurev.arplant.53.091401.143329. 